\title{
Eggs weight of Japanese quail vs. eggs quality after storage time and hatchability results
}

\author{
SEBASTIAN NOWACZEWSKI, KATARZYNA WITKIEWICZ, HELENA KONTECKA, \\ STANISŁAWA KRYSTIANIAK and ANDRZEJ ROSIŃSKI \\ Department of Poultry Science, Poznan University of Life Sciences, Poznan, Poland
}

\begin{abstract}
The aim of the performed investigations was to compare eggs of Japanese quail layers of different weights with regard to their shape, selected traits of the content following various times of their storage as well as the results of hatchability and body weight of one-day old chicks. Hatching eggs were divided into four groups: group $\mathrm{S}-$ up to $10.50 \mathrm{~g}$, group $\mathrm{M}$ - from 10.51 to $11.50 \mathrm{~g}$, group $\mathrm{L}$ - from 11.51 to $12.50 \mathrm{~g}$ and group $\mathrm{XL}$ - from $12.51 \mathrm{~g}$. In experiment I, on days: 1, 3, 5, 7 and 10 of storage, the following traits were assessed in 20 eggs from each group: egg weight $(\mathrm{g})$ and yolk and albumen index as well as the number of Haugh units. In experiment II, five hatches were carried out. The total of 480 eggs were incubated in each hatch (120 eggs for each group). On the 15th day of incubation, the eggs were weighed. After hatching, 30 chicks from each group were weighed. Basic hatchability indices were also determined. Eggs with the smallest weight, stored for 1 day, with the smallest yolks were characterized by their highest content contrary to the eggs with the highest weight (the biggest yolks but with their smallest percentage content). In eggs with the higher weight (groups $L$ and $X L$ ), a certain increase in weight and proportion (\%) of yolk was observed after $3,5,7$ and 10 days. The highest albumen percentage content was determined in eggs from groups $L$ and $X L$, whereas in the remaining groups the albumen content was the smallest. With the lengthening of the egg storage, the albumen weight did not undergo significant changes. After one-day storage, the yolk and albumen index as well as Haugh units were slightly higher for eggs of smaller weight than for bigger ones. Eggs from groups $\mathrm{S}$ and $\mathrm{M}$ were more spherical. Eggs from groups $L$ and $X L$ had smaller weight losses during hatching. Eggs from group $L$ were characterized by the best fertilization, hatchability results and proportion of dead embryos and unhatched chicks. The heaviest chicks were obtained from eggs of the highest weight, while the lightest - from eggs of the smallest weight. The obtained results appear to indicate that Japanese quail eggs of 10.51-12.50 $\mathrm{g}$ are the best for hatching.
\end{abstract}

Keywords: Japanese quail, egg weight, egg quality, hatchability

\section{Zusammenfassung}

\section{Gewichte und Qualität von Eiern der Japanischen Wachtel im Zusammenhang mit Lagerungszeit und Schlupfergebnissen}

Verglichen wurden Wachteleier mit unterschiedlichem Gewicht hinsichtlich ihrer Form, ausgewählten Gehaltsmerkmalen, unterschiedlicher Lagerungszeit, den Schlupfergebnissen 
sowie den Gewichten der Eintagskücken. Die Gewichtsgruppen der Bruteier waren S Gruppe bis $10,5 \mathrm{~g}, \mathrm{M}=10,51-11,50, \mathrm{~L}=11,51-12,50$ und $\mathrm{XL}=$ über $12,51 \mathrm{~g}$. Im 1. Versuch wurden am 1., 3., 5., 7. und 10. Tag bei 20 Eiern jeder Gruppe folgende Merkmale bestimmt: Ei- und Eigelbgewicht sowie Eiweißindex (\%), Zahl der Haugh-Einheiten. Im 2. Versuch erfolgten fünf Bruten mit je 120 Eiern je Gruppe. Von jeweils 30 Kücken wurden das Gewicht sowie die Schlupfergebnisse bei den Gruppen erfasst. Die leichtesten Eier mit dem kleinsten Eigelb zeigten nach eintägiger Lagerung die höchsten Gehaltswerte gegenüber den schwersten Eiern mit größerem Eigelb aber den geringeren Gehalten. Bei Eiern der Gruppen L und XL fand sich nach dem 3. bis 10. Tag ein Gewichtszuwachs und höherer Eigelbanteil. Ein größerer prozentualer Eiweißanteil wurde bei den M und XL Gruppen und ein geringerer bei den übrigen Gruppen nachgewiesen. Bei Verlängerung der Lagerungszeit fanden sich hinsichtlich der Eiweißgewichte keine signifikanten Veränderungen. Sowohl Eigelb und Eiweißindex als auch Haugh-Einheiten waren nach eintägiger Lagerung bei leichteren Eiern höher als bei den schwereren Eiern. Eier der S und M Gruppe waren kugeliger. Geringere Verluste während der Brut fanden sich bei den L und XL Gruppen. Die besten Werte hinsichtlich Befruchtung, Schlupfleistung, abgestorbener Embryonen und nicht geschlüpfter Kücken zeigte die L Gruppe. Die schwersten Kücken erreichte die XL und die leichtesten die S Gruppe. Es wird abgeleitet, dass für gute Brutergebnisse Wachteleier mit einem Gewicht von 10,51 bis 12,50 g ausgewählt werden sollten.

Schlüsselwörter: japanische Wachtel, Eiermasse, Eierqualität, Schlupfleistung

\section{Introduction}

Japanese quails are characterized by laying similar to that of hens (BAUMGARTNER 1994, KOŹLECKA et al. 2006). A prolonged, year-long laying period and egg production during this period all indicate usefulness of investigations of Japanese quail eggs. It should be stressed that Japanese quails reach sexual maturity very early (approximately at 6th week of life) which can be related to a deteriorating egg quality at the peak of laying (NASROLLAH et al. 2006, ADAMSKI 2008). In experiments on quality (MIELENZ et al. 2000, KUL and SEKER 2004, RI et al. 2005, MENNICKEN et al. 2005, AYASAN et al. 2006, TARASEWICZ et al. 2006, SEZER 2007, SULTANA et al. 2007, ADAMSKI 2008, NOWACZEWSKI et al. 2010) the above researchers analysed such external egg traits as: dimensions (width and length), shape and shell index as well as the egg content - yolk and albumen features and based their quality assessment of these eggs on their origin and age. In addition, they also examined the impact exerted by different concentrations in feeds of protein and nutritional additives, e.g. probiotics as well as different sources of fat. The above investigations focused mainly on the evaluation of the eggshell quality which deteriorate significantly at the peak of laying (DURMUS et al. 2004).

It is well known, that external and internal egg traits also can be significantly influenced by the storage time and egg size. Together with the lengthening of the storage period, unfavourable physicochemical changes of their content take place (JONES and MUSGROVE 2005, SAMLI et al. 2005). In hens, it was noticed that eggs stored for more than 10 days were characterized by worse, in comparison with those examined on the day of laying ( 0 days of storage), white and yolk indices and lower number of Haugh units (YILMAZ and BOZKURT 2009). Similar results were obtained by DEMIREL and KIRIKÇI (2009) in pheasants (Phasianus 
colchicus). Eggs after 1-2 days of storage were characterized by higher values of the white and yolk indices and number of Haugh units than eggs examined in 9th or 10th day of storage. On the other hand, in the investigations carried out on the rock partridge (Alectoris graeca), no significant differences were recorded in the white index and the number of Haugh units when egg quality was analysed after 1-2 and 9-10 days of storage (CAĞLAYAN et al. 2009). ŞEKEROĞLU and ALTUNTAŞ (2009), when evaluating eggs (small, medium, large and extralarge) of brown-egg layer hens, reported that yolk and albumen height increased with egg size. On the other hand, deteriorating egg quality, especially white and shell traits, may be one of the causes of obtaining worse hatching results (ROQUE and SOARES 1994, LUYKX after NARUSHIN and ROMANOV 2002).

The reproduction potential of Japanese quails is apparent not only in the number of laid eggs by also in their high fertilization as well as very good egg hatchability results (BAUMGARTNER 1994, ADAMSKI 2008). In their investigations, ALKAN et al. (2008) reported a significant influence of the weight of Japanese quail eggs on hatchability traits and demonstrated declining values of hatchability traits together with the increase of egg weight over $12 \mathrm{~g}$. Similar relationships between the weight of Japanese quail (meat type) eggs and hatchability results were found by PETEK et al. (2003) and PETEK et al. (2005). The impact of egg weight on hatchability traits was also determined in other poultry species (among others, in turkey, guinea fowl and geese) (MACHAL et al. 1994, APPLEGATE and LILBURN 1996, NARUSHIN and ROMANOV 2002, ISGUZAR 2005, ADAMSKI 2008).

The results of the above-mentioned studies inspired the authors to undertake investigations aiming at comparing eggs of different weights with reference to their shape, selected traits of content at various times of their storage as well as hatchability results and body weight of hatched chicks.

\section{Material and methods}

The experimental material comprised hatching eggs of Japanese quail of laying type derived from a private farm. The birds began laying in the 7th week of life at $150 \mathrm{~g}$ mean body weight. Experimental birds were kept in cages and fed ad libitum complete diets which contained in $1 \mathrm{~kg}: 11.7 \mathrm{MJ}$ metabolizable energy, $21 \%$ crude protein and $3.1 \%$ calcium.

Two experiments were carried out for which eggs were selected from all the eggs laid on a given day and assigned to 4 groups depending on their weight as follows: group $\mathrm{S}$ - up to $10.50 \mathrm{~g}$, group $\mathrm{M}$ - from 10.51 to $11.50 \mathrm{~g}$, group $\mathrm{L}$ - from 11.51 to $12.50 \mathrm{~g}$ and group XL - from $12.51 \mathrm{~g}$. Eggs were weighed on a RADWAG WPS 360C type balance.

\section{Experiment 1}

The first experiment was conducted when Japanese quails were in their 14th week of life. The total of 400 eggs (100 eggs in each group) were selected and were stored at the temperature of $15^{\circ} \mathrm{C}$ and mean relative air humidity of $47 \%$. On days: $1,3,5,7$ and 10 of storage, the following traits were assessed in 20 eggs from each group:

- Yolk weight $(\mathrm{g})$ with $0.01 \mathrm{~g}$ accuracy and its percentage proportion was calculated,

- Yolk index (\%) on the basis of the ratio of the yolk height $(\mathrm{mm})$ - measurement taken with 
a three-legged micrometer screw to the yolk width $(\mathrm{mm})$ measured along the chalaza line with the assistance of an electronic slide calliper with $0.02 \mathrm{~mm}$ accuracy,

- Albumen weight (g) calculated by subtracting from the egg weight, the weight of the yolk and eggshell and the percentage proportion of the albumen in the egg was determined,

- Albumen index (\%) on the basis of the ratio of the thick albumen height $(\mathrm{mm})$ measurement taken with a three-legged micrometer screw to the width of this albumen $(\mathrm{mm})$ measured with the assistance of an electronic slide calliper with $0.02 \mathrm{~mm}$ accuracy,

- Haugh units according to the formula (WILLIAMS 1992)

$$
J H=100 \lg \left(H+7.7-1.7 W^{0.37}\right)
$$

where $H$ is the height of the thick albumen, $W$ is the egg weight.

\section{Experiment II}

The second experiment was conducted in five replications and eggs for it derived from Japanese quails $10,15,20,25$ and 30 weeks of age. The total of 2400 eggs were selected which were stored for one day in a room in which the temperature of $15^{\circ} \mathrm{C}$ and mean relative air humidity of $47 \%$ were maintained. 480 eggs were allocated to each replication, i.e. 120 eggs to each group and their lengths and widths with $0.02 \mathrm{~mm}$ accuracy were measured using an electronic slide calliper. Prior to their setting in the hatching apparatus, eggs were disinfected using $75 \%$ ethyl alcohol. Eggs incubation were carried out in a single-set incubator of the Jamesway Company. Up to day 14, eggs were kept in the setting compartment in which the temperature was kept at $37.6^{\circ} \mathrm{C}$ and mean relative air humidity at $52 \%$ and on day 15 they were transferred to the hatching compartment with temperature of $37.4^{\circ} \mathrm{C}$ and mean relative air humidity - at $60-70 \%$. After chick hatching (17th day of incubation), 30 birds were randomly selected from each group and weighed. After termination of the hatching process, eggs from which no chicks were hatched were opened in order to determine the number of non-fertilized eggs, eggs with dead embryos and with unhatched chicks.

On the basis of the collected data, the following were calculated:

- Egg shape index (\%) - from the ratio of egg width to length,

- Egg weight loss (\%) - from the difference of the egg weight before setting and on day 15 of incubation,

- Egg fertilization (\%),

- Proportion (\%) of dead embryos and unhatched chicks to fertilized eggs,

- Hatchability from fertilized eggs (\%),

- Hatchability from set eggs (\%).

\section{Statistics}

Statistical calculations were conducted with the assistance of the SAS v. 9.1 package. Mean values $(\bar{x})$ as well as the standard error of the mean (SEM) were calculated for all traits. Differences between groups (experiment I) in every day of storage and between days in every group with regard to the internal traits of egg were determined employing the oneway linear model of the analysis of variance which assumed the following form:

$$
Y_{i j}=\mu+g_{i}+e_{i j}
$$


where $Y_{i j}$ is the phenotypic value of the trait for the $j$-th egg in $i$-th group/i-th day, $\mu$ is the mean value of the trait for a given population, $g_{i}$ is the effect of $i$-th group $(j=1,2,3,4)$ or effect of $i$-th group $(j=1,2,3,4,5), e_{i j}$ is the effect of experimental error.

Differences between groups (experiment II) with regard to the shape index, egg weight loss and hatchability traits were determined using the two-way linear model of the analysis of variance which assumed the following form:

$$
y_{i j k}=\mu+g_{i}+a_{j}+e_{i j k}
$$

where $y_{i j k}$ is the phenotypic value of the trait for the $k$-th egg in the $i$-th group for $j$-th age of birds, $\mu$ is the mean value of the trait for a given population, $g_{i}$ is the effect of $i$-th group $(i=1$, $2,3,4), a_{j}$ is the effect of $j$-th age $(j=1,2,3,4,5), e_{i j k}$ is the effect of experimental error.

\section{Results and discussion}

No publications were found in literature dealing with the evaluation of Japanese quail egg content at various periods of their storage depending on their weight. Only two papers were found (GONZÁLEZ 1995, GÜÇLÜ et al. 2008) in which the authors investigated some traits of the egg yolk and albumen following their storage for one day. The weight of yolk, irrespective of the egg storage period, differed statistically significantly between groups (Table 1). Following one day of storage, eggs with the smallest weight (group S) were characterized by a significantly greater (by about 2.3 percentage points) yolk content than eggs with the greatest weight (group XL) and from group L. Higher yolk content (by 1.4 percentage points) was observed after 3 days of storage for eggs from groups $M$ and XL in comparison with group $S$. Also after 5 days of storage, eggs with higher weight $(\geq 12.50 \mathrm{~g}$ ) were found to have a higher $(P \leq 0.05)$ value of this trait (by about 1.5 percentage point) than eggs from groups $S$ and $M$.

Table 1

Estimates of examined traits of yolk at various storage time Eigelbmerkmale der Wachteleier bei unterschiedlicher Lagerungszeit

\begin{tabular}{|c|c|c|c|c|c|c|c|c|c|c|c|}
\hline \multirow[t]{3}{*}{ Trait } & \multirow[t]{3}{*}{ Group } & \multicolumn{10}{|c|}{ Day of storage } \\
\hline & & \multicolumn{2}{|c|}{1} & \multicolumn{2}{|c|}{3} & \multicolumn{2}{|c|}{5} & \multicolumn{2}{|c|}{7} & \multicolumn{2}{|c|}{10} \\
\hline & & Mean & SEM & Mean & SEM & Mean & SEM & Mean & SEM & Mean & SEM \\
\hline Yolk & $\mathrm{S}$ & $3.23^{\mathrm{Ad}}$ & 0.07 & $3.00^{B d}$ & 0.08 & $3.04^{\mathrm{ABd}}$ & 0.06 & $3.15^{\mathrm{Ad}}$ & 0.06 & $3.0^{\mathrm{ABd}}$ & 0.06 \\
\hline \multirow[t]{3}{*}{ weight, g } & $M$ & $3.46^{A B C}$ & 0.06 & $3.55^{\mathrm{Ac}}$ & 0.05 & $3.38^{\mathrm{BC}}$ & 0.04 & $3.52^{A C}$ & 0.05 & $3.51^{A B C}$ & 0.04 \\
\hline & $\mathrm{L}$ & $3.65^{\mathrm{Ab}}$ & 0.04 & $3.78^{A B b}$ & 0.04 & $3.82^{\mathrm{ABb}}$ & 0.05 & $3.85^{\mathrm{Bb}}$ & 0.07 & $3.81^{\mathrm{ABb}}$ & 0.09 \\
\hline & $X L$ & $3.90^{\mathrm{Ca}}$ & 0.07 & $4.31^{\mathrm{ABa}}$ & 0.06 & $4.30^{\mathrm{ABa}}$ & 0.09 & $4.37^{\mathrm{Aa}}$ & 0.08 & $4.14^{\mathrm{Ba}}$ & 0.08 \\
\hline Yolk & $\mathrm{S}$ & $32.6^{\mathrm{Aa}}$ & 0.79 & $30.9^{B b}$ & 0.56 & $31.0^{A B b}$ & 0.48 & $32.4^{\mathrm{ABa}}$ & 0.52 & $31.0^{\mathrm{ABa}}$ & 0.48 \\
\hline \multirow[t]{3}{*}{ content, $\%$} & $M$ & $31.2^{\mathrm{ABab}}$ & 0.42 & $32.4^{\mathrm{Aa}}$ & 0.47 & $30.8^{\mathrm{Bb}}$ & 0.38 & $31.8^{\mathrm{ABa}}$ & 0.49 & $31.6^{\mathrm{ABa}}$ & 0.43 \\
\hline & $\mathrm{L}$ & $30.6^{A b}$ & 0.37 & $31.8^{\mathrm{ABab}}$ & 0.3 & $31.9^{\mathrm{ABab}}$ & 0.43 & $32.2^{\mathrm{Ba}}$ & 0.52 & $31.8^{\mathrm{ABa}}$ & 0.74 \\
\hline & $X L$ & $29.9^{A b}$ & 0.45 & $32.3^{\mathrm{Ba}}$ & 0.3 & $32.4^{\mathrm{Ba}}$ & 0.48 & $32.8^{\mathrm{Ba}}$ & 0.51 & $31.6^{\mathrm{Ba}}$ & 0.63 \\
\hline Yolk & $\mathrm{S}$ & $49.9^{\mathrm{ABa}}$ & 0.8 & $51.3^{\mathrm{Aa}}$ & 0.68 & $49.0^{\mathrm{BCa}}$ & 0.69 & $50.8^{\mathrm{ABa}}$ & 0.56 & $47.4^{\mathrm{Ca}}$ & 0.61 \\
\hline \multirow[t]{3}{*}{ index, $\%$} & $M$ & $50.3^{\mathrm{Aa}}$ & 0.85 & $49.9^{\text {Aab }}$ & 0.71 & $49.2^{\mathrm{ABa}}$ & 0.65 & $47.8^{\mathrm{BCb}}$ & 0.66 & $45.9^{\mathrm{Cab}}$ & 0.59 \\
\hline & $\mathrm{L}$ & $48.8^{\mathrm{Aa}}$ & 0.44 & $48.7^{A b c}$ & 0.43 & $46.9^{\mathrm{Bb}}$ & 0.57 & $47.4^{\mathrm{Bb}}$ & 0.55 & $46.1^{\text {Bab }}$ & 0.61 \\
\hline & $X L$ & $48.6^{\mathrm{Aa}}$ & 0.42 & $47.2^{A c}$ & 0.56 & $44.4^{B C}$ & 0.45 & $45.5^{\mathrm{BC}}$ & 0.53 & $45.2^{\mathrm{Bb}}$ & 0.55 \\
\hline
\end{tabular}

Means in columns, within trait, with different small letters differ significantly at $P \leq 0.05$; Means in rows, within group, with different capital letters differ significantly at $P \leq 0.05$ 
In the case of the yolk index, no statistically significant differences were observed between groups of eggs stored for 1 day (Table 1). Eggs from group $S$ after 3 and 5 days and from group $\mathrm{M}$ - alter 5 days were characterized by a significantly higher ( 2.4 and 2.3 percentage points, respectively) values of the yolk index in comparison with eggs from group $L$ (from 11.51 to $12.50 \mathrm{~g}$ ). In addition, after 3 and 5 days of storage, the yolk index for eggs with the smallest weight as well as from group $M$ was significantly higher than for the heaviest eggs on average, by 4.1 percentage points. It should also be indicated that eggs stored for 5 days from group $L$ in comparison with group $X L$ had the value of this trait by 2.5 percentage points higher $(P \leq 0.05)$. On the other hand, eggs after 7 days of storage with the smallest weight were characterized by significantly greater (by about 3.2 percentage points) yolk index than eggs from groups $M$ and $L$ and by 5.3 percentage points greater in comparison with the heaviest eggs ( $\geq 12.50 \mathrm{~g}$ ). It should be added that eggs from groups $M$ and $L$ had a significantly higher (on average, by 2.1 percentage points) value of this trait than the heaviest eggs. After 10-day storage, also in the case of the lightest eggs $(\leq 10.5 \mathrm{~g})$ in comparison with the heaviest ones, a 2.2 percentage points higher $(P \leq 0.05)$ value of the yolk index was determined.

After 1-day storage, in comparison with the eggs of the smallest weight, both the heaviest eggs as well as eggs from group $L$ were characterized by a significantly higher (by about 2.8 percentage points) albumen content, whereas eggs from group $\mathrm{XL}$ - by 2.0 percentage points higher in comparison with the eggs from group $M$ (Table 2). On the other hand, eggs stored for 3 days with the smallest weight were found to have a significantly higher (on average, by 1.3 percentage points) value of this trait in comparison with the eggs from groups $\mathrm{M}$ and $\mathrm{XL}$.

Table 2

Estimates of examined traits of albumen Eiweißmerkmale der Wachteleier

\begin{tabular}{|c|c|c|c|c|c|c|c|c|c|c|c|}
\hline \multirow[t]{3}{*}{ Trait } & \multirow[t]{3}{*}{ Group } & \multicolumn{10}{|c|}{ Day of storage } \\
\hline & & \multicolumn{2}{|c|}{1} & \multicolumn{2}{|c|}{3} & \multicolumn{2}{|c|}{5} & \multicolumn{2}{|c|}{7} & \multicolumn{2}{|c|}{10} \\
\hline & & Mean & SEM & Mean & SEM & Mean & SEM & Mean & SEM & Mean & SEM \\
\hline \multirow{4}{*}{$\begin{array}{l}\text { Albumen } \\
\text { weight, g }\end{array}$} & $S$ & $5.89^{\mathrm{Ad}}$ & 0.1 & $5.87^{\mathrm{Ad}}$ & 0.12 & $6.00^{\mathrm{Ad}}$ & 0.13 & $5.87^{\mathrm{Ad}}$ & 0.12 & $6.09^{\mathrm{Ad}}$ & 0.08 \\
\hline & $M$ & $6.74^{\mathrm{Ac}}$ & 0.06 & $6.60^{\mathrm{Ac}}$ & 0.07 & $6.73^{\mathrm{Ac}}$ & 0.06 & $6.67^{A C}$ & 0.08 & $6.71^{\mathrm{Ac}}$ & 0.08 \\
\hline & $\mathrm{L}$ & $7.37^{\mathrm{Ab}}$ & 0.07 & $7.20^{A B b}$ & 0.06 & $7.25^{\mathrm{ABb}}$ & 0.05 & $7.16^{\mathrm{Bb}}$ & 0.06 & $7.26^{\mathrm{ABb}}$ & 0.09 \\
\hline & $X L$ & $8.19^{\mathrm{Aa}}$ & 0.12 & $8.02^{\mathrm{Aa}}$ & 0.08 & $8.00^{\mathrm{Aa}}$ & 0.08 & $7.93^{\mathrm{Aa}}$ & 0.13 & $8.00^{\mathrm{Aa}}$ & 0.12 \\
\hline \multirow{4}{*}{$\begin{array}{l}\text { Albumen } \\
\text { content, \% }\end{array}$} & $\mathrm{S}$ & $59.4^{A c}$ & 0.75 & $61.4^{\mathrm{Ba}}$ & 0.56 & $60.9^{\mathrm{ABa}}$ & 0.49 & $60.1^{\mathrm{ABa}}$ & 0.57 & $61.1^{\mathrm{Ba}}$ & 0.48 \\
\hline & M & $60.7^{\mathrm{ABbc}}$ & 0.36 & $60.0^{\mathrm{Bb}}$ & 0.48 & $61.3^{\mathrm{Aa}}$ & 0.36 & $60.3^{A B a}$ & 0.57 & $60.3^{A B a}$ & 0.47 \\
\hline & $\mathrm{L}$ & $61.7^{\mathrm{Aab}}$ & 0.4 & $60.5^{\mathrm{ABab}}$ & 0.32 & $60.4^{\mathrm{ABa}}$ & 0.43 & $60.0^{\mathrm{Ba}}$ & 0.48 & $60.5^{\mathrm{ABa}}$ & 0.73 \\
\hline & $X L$ & $62.7^{\text {Aa }}$ & 0.52 & $60.1^{\mathrm{Bb}}$ & 0.28 & $60.2^{\mathrm{Ba}}$ & 0.43 & $59.6^{\mathrm{Ba}}$ & 0.53 & $60.8^{\mathrm{Ba}}$ & 0.7 \\
\hline \multirow{4}{*}{$\begin{array}{l}\text { Albumen } \\
\text { index, } \%\end{array}$} & $\mathrm{~S}$ & $10.7^{\mathrm{Aa}}$ & 0.42 & $10.0^{\mathrm{Aa}}$ & 0.37 & $8.8^{\mathrm{Ba}}$ & 0.25 & $8.7^{\mathrm{Ba}}$ & 0.29 & $7.8^{\mathrm{Ba}}$ & 0.34 \\
\hline & $M$ & $10.1^{\text {Aab }}$ & 0.48 & $9.4^{\mathrm{ABab}}$ & 0.33 & $8.5^{\mathrm{Ba}}$ & 0.3 & $7.0^{\mathrm{cb}}$ & 0.35 & $7.2^{\mathrm{Ca}}$ & 0.23 \\
\hline & $\mathrm{L}$ & $9.1^{\mathrm{Ab}}$ & 0.23 & $8.8^{\mathrm{ABb}}$ & 0.38 & $7.6^{\mathrm{Cb}}$ & 0.32 & $7.8^{\mathrm{Cab}}$ & 0.39 & $8.0^{\mathrm{BCa}}$ & 0.28 \\
\hline & $X L$ & $9.3^{\mathrm{Ab}}$ & 0.32 & $7.9^{B C}$ & 0.21 & $6.7^{c c}$ & 0.25 & $7.0^{\mathrm{cb}}$ & 0.26 & $7.4^{\mathrm{BCa}}$ & 0.3 \\
\hline \multirow{4}{*}{$\begin{array}{l}\text { Haugh } \\
\text { units }\end{array}$} & $\mathrm{S}$ & $87.1^{\mathrm{Aa}}$ & 0.71 & $86.3^{\mathrm{Aa}}$ & 0.69 & $83.7^{\mathrm{Ba}}$ & 0.56 & $83.0^{\mathrm{Ba}}$ & 0.52 & $81.1^{\mathrm{Ca}}$ & 0.72 \\
\hline & $M$ & $87.0^{\mathrm{Aa}}$ & 0.79 & $84.6^{\mathrm{Bab}}$ & 0.67 & $82.7^{\mathrm{Ba}}$ & 0.57 & $79.5^{\mathrm{cbc}}$ & 0.79 & $79.6^{\mathrm{Cab}}$ & 0.51 \\
\hline & $\mathrm{L}$ & $84.8^{\mathrm{Ab}}$ & 0.38 & $84.1^{\mathrm{Ab}}$ & 0.78 & $80.6^{\mathrm{Bb}}$ & 0.69 & $81.2^{\mathrm{Bab}}$ & 0.93 & $81.2^{\mathrm{Ba}}$ & 0.52 \\
\hline & $X \mathrm{~L}$ & $85.4^{\mathrm{Aab}}$ & 0.64 & $81.2^{B C}$ & 0.45 & $77.9^{\mathrm{cc}}$ & 0.65 & $78.5^{\mathrm{BCC}}$ & 0.62 & $76.3^{\mathrm{Cb}}$ & 2.15 \\
\hline
\end{tabular}

Means in columns, within trait, with different small letters differ significantly at $P \leq 0.05$, Means in rows, within group, with different capital letters differ significantly at $P \leq 0.05$ 
Eggs stored for 1, 3 and 5 days with the lowest weight were found to have by about 1.6 percentage points higher value of the albumen index than eggs from groups $L$ and XL (Table 2). Also eggs from group $M$, after 5 days of storage, were characterized by a significantly (by 0.9 percentage points) higher value of this trait than eggs from group $L$ and after 3 and 5 days of storage - on average by 1.7 percentage points higher than eggs from group XL. In addition, for the eggs from group $L$, in comparison with group $X L$ after 3 and 5 days of storage, the value of the albumen index was found to be by 0.9 percentage points higher. After the 7th day of storage, eggs with the smallest weight were still found to have a significantly higher value of this trait (by 1.7 percentage points) in comparison with the heaviest eggs as well as eggs from group $\mathrm{M}$.

Eggs from group $\mathrm{S}$ stored for 1, 3 and 5 days and from group $\mathrm{M}$ - for 1 and 5 days were characterized by a significantly higher Haugh unit number value, respectively, about 2.5 and 1.7 in comparison with group L. After 3 and 5 days, the eggs from groups $S$ and $M$ were found to have, on average, by $4.7(P \leq 0,05)$ and eggs from group $L$ - by about 2.8 higher values of Haugh units than eggs from group XL. In the case of eggs with the smallest weight, also after 7 days of storage the value of this trait was significantly higher (on average by 4) in comparison with the values determined for eggs from groups $\mathrm{M}$ and $\mathrm{XL}$. In addition, eggs from group $L$ were characterized by a higher value of Haugh units than eggs from group $X L$. On the other hand, following the longest storage period (10 days), eggs from groups $S$ and $L$, in comparison with group $\mathrm{XL}$, had significantly higher values of this trait (by about 4.9).

The results of egg content assessment obtained in this study are comparable with those found in other publications. For example, GONZÁLEZ (1995) and GÜÇLÜ et al. (2008), when evaluating eggs of Japanese quail which were 2 weeks younger than the birds in the present study, reported similar values of the yolk and albumen index and Haugh units to those found in the performed investigations for eggs from groups $M$ and L. However, it should be said that Japanese quails from the study by GONZÁLEZ (1995) were fed a complete diet of higher energy value (it contained by $0.6 \mathrm{MJ}$ more metabolizable energy than in experiment) which, according to BEDNARCZYK (1991) may affect the quality of egg yolk and albumen. On the other hand, GÜÇLÜ et al. (2008) used different fat sources in their complete diets but their energy values as well as the crude protein content were identical as in investigations. Values of all yolk and albumen traits determined in experiments in groups $M$ and $L$ following oneday egg storage were similar to the values reported by other researchers (KUL and SEKER 2004, SEKER 2004, Rl et al. 2005), although in those investigations eggs derived from older Japanese quails (20th week of life).

On the other hand, GRINDSTAFF et al. (2005), assessing eggs of $8.8 \mathrm{~g}$ mean weight obtained from 8-week old laying Japanese quails, obtained yolk weight similar to that determined in experiments from group $S$ in the case of eggs stored for one day. Yannakopoulos and Tserveni-Gousi (after SHANAWAY 1994) reported that Japanese quails, up to the 11th week of life, in comparison with birds aged 12 to 22 weeks laid eggs of smaller weight with a smaller proportion of the yolk. Also ADAMSKI (2008) reported a smaller egg weight as well as smaller weight and proportion of the yolk in eggs in Japanese quails in the first stage of laying (up to the peak of laying). Therefore, in comparison with experiments, GRINDSTAFF et al. (2005) should have determined smaller yolk weight in eggs. The fact that the above researchers obtained a similar weight of this morphological constituent could have resulted from 
the origin of their Japanese quails because they evaluated eggs derived from a breeding selection line of Japanese quails.

In investigations conducted by OLIVEIRA et al. (2007) on eggs (from control groups) which were not stored, they reported higher values of Haugh units (on average by 4.4) than those obtained in this study for eggs from groups $\mathrm{M}$ and L. It should, however, be added that eggs assessed by those researchers were obtained from birds which were two times older (28th week of life).

The smallest yolk value index was determined in the eggs derived from group $\mathrm{S}$ after 10 days of storage (47.4\%). In group $M$, smaller yolk indices than after day 1 and 3 were determined after 7 and 10 days of storage. The differences were statistically significant and amounted to about 3.3 percentage points. In eggs from groups $L$ and $X L$ after 1 and 3 days of storage, the values of the discussed trait were similar and statistically significantly higher, on average by 2.5 percentage points, in comparison with the eggs stored longer. In the case of eggs from all groups stored for 5, 7 and 10 days, the authors determined similar albumen index values ( $\bar{x}=7.7 \%$ ) which were by about 2.1 percentage points smaller in comparison with the first day as was the case with the number of Haugh units. In groups $S$ and $L$, after 1 and 3 days of storage, a similar (about 85.6$)$ and higher $(P \leq 0.05)$ value of this trait was observed in comparison with the remaining days on which the number of Haugh units averaged 81.8. On the other hand, eggs from groups $M$ and $X L$ stored for 1 day were characterized by a statistically significantly higher value of this trait in comparison with the remaining periods of storage. The differences amounted to 5.4 and 6.9 Haugh units, respectively. In the case of the white index and number of Haugh units, a much lower than in fresh hens eggs values of these traits were demonstrated after 7, 10 and 14 days of storage and the difference amounted to $4.8 \%$ and 23.6 points, respectively (AKYUREK and OKUR 2009). In the rock partridges, TILKI and SAATCI (2004) reported deterioration of white quality when eggs were stored for 7 and 14 days, although on both of the above dates similar and not varying from one another values of Haugh units were recorded ( $\bar{x}=81.7$ points). DEMIREL and KIRIKÇI (2009) did not notice significant deterioration of white quality in pheasant eggs stored for 1-8 days.

Eggs from groups $S$ and $M$ were characterized by statistically significantly higher values of the shape index (on average, by 0.5 and 0.9 percentage points) in comparison with groups $L$ and $X \mathrm{~L}$, respectively (Table 3 ). This indicates that eggs of smaller weight were more spherical. It should be added that eggs from group $L$ had a significantly higher (by 0.4 percentage points) value of this trait than eggs from group $X L(\geq 12.50 \mathrm{~g})$. The egg shape index determined in group $M$ was by 1.3 percentage points higher in comparison with that reported in an earlier paper (GONZÁLEZ 1995) for eggs of $10.7 \mathrm{~g}$ mean weight which were obtained from Japanese quails at comparable age with those assessed in this study.

During hatching, eggs from groups $\mathrm{L}$ and $\mathrm{XL}$ had a statistically significantly lower weight losses (by about 1.3 and 0.7 percentage points) in comparison with groups $S$ and $M$, respectively. In addition, weight loss of eggs from group $M$ (from 10.51 to $11.50 \mathrm{~g}$ ) was by 0.6 percentage points smaller in comparison with eggs from group $S$. The hatchability from fertilized and set eggs in group L was statistically significantly higher by, respectively 6.8 and 9.3 percentage points in comparison with group $\mathrm{S}(\leq 10.50 \mathrm{~g})$. In the case of fertilized eggs as well as the proportion of necrosed embryos and unhatched chicks, no significant differences between groups were observed. Nevertheless, the best values of the above-mentioned traits 
were determined in the eggs from group $L(95.2 ; 1.6$ and $7.7 \%$, respectively). On the other hand, the heaviest one-day old chicks were noticed in group $X L$ and the lightest $(6.8 g)$ - in group $S$.

Table 3

Estimates of eggs shape index, eggs weight loss, hatchability results and one-day old chicks weight

Schätzung von Formindex und Eiermasseverluste und Ergebnisse der Schlupfleistung und der Masse von Eintagswachteln

\begin{tabular}{lcccccccc}
\hline Trait & \multicolumn{2}{c}{ Group S } & \multicolumn{2}{c}{ Group M } & \multicolumn{2}{c}{ Group L } & \multicolumn{2}{c}{ Group XL } \\
& Mean & SEM & Mean & SEM & Mean & SEM & Mean & SEM \\
\hline Egg shape index,\% & $79.4^{\mathrm{a}}$ & 0.14 & $79.2^{\mathrm{a}}$ & 0.11 & $78.8^{\mathrm{b}}$ & 0.13 & $78.4^{\mathrm{c}}$ & 0.12 \\
Egg weight loss, \% & $11.0^{\mathrm{a}}$ & 0.16 & $10.4^{\mathrm{b}}$ & 0.17 & $9.9^{\mathrm{c}}$ & 0.15 & $9.5^{\mathrm{c}}$ & 0.15 \\
Egg fertilization,\% & $91.7^{\mathrm{a}}$ & 2.24 & $92.1^{\mathrm{a}}$ & 1.67 & $95.2^{\mathrm{a}}$ & 0.76 & $94.9^{\mathrm{a}}$ & 1.7 \\
Hatchability from fertilized egss, \% & $83.9^{\mathrm{a}}$ & 0.8 & $87.9^{\mathrm{ab}}$ & 1.76 & $90.7^{\mathrm{b}}$ & 1.55 & $87.1^{\mathrm{ab}}$ & 1.6 \\
Hatchability from set egss, \% & $77.0^{\mathrm{a}}$ & 2.38 & $81.0^{\mathrm{ab}}$ & 2.68 & $86.3^{\mathrm{b}}$ & 1.2 & $82.8^{\mathrm{ab}}$ & 2.6 \\
Dead embryos, \% & $3.4^{\mathrm{a}}$ & 1.27 & $2.4^{\mathrm{a}}$ & 0.59 & $1.6^{\mathrm{a}}$ & 0.64 & $3.1^{\mathrm{a}}$ & 0.91 \\
Unhatched chicks, \% & $12.7^{\mathrm{a}}$ & 1.19 & $9.7^{\mathrm{a}}$ & 1.34 & $7.7^{\mathrm{a}}$ & 1.19 & $9.8^{\mathrm{a}}$ & 0.89 \\
Chicks weight, g & $6.9^{\mathrm{a}}$ & 0.04 & $7.8^{\mathrm{b}}$ & 0.03 & $8.4^{\mathrm{c}}$ & 0.03 & $9.4^{\mathrm{d}}$ & 0.04 \\
\hline
\end{tabular}

Mean values designated in rows with different letters differ significantly at the level $P \leq 0.05$

Egg fertilization determined in eggs from group $\mathrm{S}$ was by 4 percentage points higher than in studies by IPEK et al. (2004) who evaluated eggs of $10.3 \mathrm{~g}$ mean weight derived from Japanese quails at the age comparable to that in this study. The higher fertilization recorded in experiment may indicate, among others, a better biological value of the employed eggs or appropriate environmental-feeding program applied by the breeder. Egg fertilization in experiments carried out by IPEK et al. (2004) could have been influenced by feeding because the authors fed birds a complete diet containing less protein (18\%) and energy (11.3 MJ) in comparison with investigations (21\% and $11.7 \mathrm{MJ}$ EM). Egg fertilization, according to WOODARD et al. (1973), Narahari et al. (after SHANAWAY 1994) and SHANAWAY (1994) depends on many factors, namely, on the number of females per one male, body weight, age and health condition of birds or environmental-feeding program. Despite lower egg fertilization, the above mentioned researchers (IPEK et al. 2004) reported a 3.4 percentage points higher hatchability from fertilized eggs in comparison with group $S(\leq 10.50 \mathrm{~g})$ in this study.

The hatchability from set eggs recorded in group $S$ in this study was similar to that reported by IPEK et al. (2004). Moreover, in this study, in comparison with the investigations of the above researchers, the authors found a considerably smaller (by up to 11.3 percentage points) proportion of necrosed embryos which may indicate a high biological value of the assessed eggs as well as the application of the appropriate hatching technique. On the other hand, the weight of one-day old chicks recorded in group $L$ was similar to that reported by TSERVENI-GOUSI (1987) in which mean egg weight was $12.2 \mathrm{~g}$. The eggs from that study derived from Japanese quails of the age comparable with the birds in this experiment; in addition, eggs were stored for one day. When assessing eggs of six poultry species, including Japanese quails, ADAMSKI (2008) found that the smallest and biggest eggs should not be used for hatching because weight as well as the proportion (\%) of morphological constituents, among others yolk and albumen (in other words - water) is inappropriate (too much or too little). In such cases worse hatchability results (more eggs with necrosed embryos) and chick 
hatching (more unhatched, weak and crippled) are obtained as also confirmed by studies.

Recapitulating, the obtained results indicate that the most suitable eggs for hatching are those weighing 10.51 to $12.50 \mathrm{~g}$. It was also found that the heaviest chicks were obtained from eggs of the highest weight, while the lightest ones from eggs of the smallest weight.

\section{References}

Adamski M (2008) Relationship between egg constituency and hatchability results of selected species of poultry. Rozprawy nr 130. Wydawnictwa Uczelniane Uniwersytetu Technologiczno-Przyrodniczego Bydgoszcz, 5-100 [in Polish]

Akyurek H, Okur AA (2009) Effect of storage time, temperature and hen age on egg quality in free-range layer hens. J Anim Vet Adv 8, 1953-8

Alkan S, Karabag K, Galic A, Balcioglu MS (2008) Effects of genotype and egg weight on hatchability traits and hatching weight in Japanese quail. South Afr J Anim Sci 38, 231-7

Applegate TJ, Lilburn MS (1996) Independent effects of hen age and egg size on incubation and poult characteristics in commercial turkeys. Poult Sci 75, 1210-6

Ayasan T, Ozcan BD, Baylan M, Canogullari S (2006) The effects of dietary inclusion of probiotic Protexin on egg yield parameters of Japanese quails (Coturnix coturnix japonica). Int J Poult Sci 5, 776-9

Baumgartner J (1994) Japanese quail production, breeding and genetics. World's Poult Sci J 50, 227-35

Bednarczyk M (1991) Influence of heredity factors and environmental conditions on eggs quality in hens. Technologia jaj. WNT Warszawa 83-106 [in Polish]

Cağlayan T, Alaşahan S, Kirikçi K, Günlü A (2009) Effect of different egg storage periods on some egg quality characteristics and hatchability of partridges (Alectoris graeca). Poult Sci 88, 1330-3

Demirel S, Kirikçi K (2009) Effect of different egg storage times on some egg quality characteristics and hatchability of pheasants (Phasianus colchicus). Poult Sci 88, 440-4

Durmuş I, Ataşoğlu C, Mizrak C, Ertaş S, Kaya M (2004) Effect of increasing zinc concentration in the diets of brown parent stock layers on various production and hatchability traits (short communication). Arch Tierz $47,483-9$

González M (1995) Influence of age on physical traits of Japanese quail (Coturnix coturnix japonica) eggs. Ann Zootech 44, 307-12

Grindstaff JL, Demas GE, Ketterson ED (2005) Diet quality affects egg size and number but does not reduce maternal antibody transmission in Japanese quail Coturnix japonica. J Anim Ecol 74, 1051-8

Güçlü BK, Uyank F, șşan KM (2008) Effect of dietary oil sources on egg quality, fatty acid composition of eggs and blond lipids in laying quail. South Afr J Anim Sci 38, 91-100

Ipek A, Sahan U, Yilmaz B (2004) The effect of live weight, male to female ratio and breeder age on reproduction performance in Japanese quails (Coturnix coturnix japonica). South Afr J Anim Sci 34, 130-4

Isguzar E (2005) Some egg and hatching traits of local ducks, Turkish Pekins and Muscovy ducks in Isparta/ Turkey (short communication). Arch Tierz 48, 94-100

Jones DR, Musgrove MT (2005) Effects of extended storage on egg quality factors. Poult Sci 84, 1774-7

Koźlecka M, Szukalski G, Wencek E (2006) Results of poultry performance evaluation in 2005. Krajowa Rada Drobiarstwa-Izba Gospodarcza Warszawa, 5-123 [in Polish]

Kul S, Seker I (2004) Phenotypic correlations between some external and internal egg quality traits in the Japanese quail (Coturnix coturnix japonica). J Poult Sci 3, 400-5

Machal L, Ingr I, Kalova J, Abek SJ (1994) The dependence of the hatchability, laying and egg weight on the egg cholesterol level and cholesterol and total lipids concentration in the blood plasma in hens of laying strains. Arch Tierz 37, 567-75

Mennicken L, Ponsuksili S, Tholen E, Khang NTK, Steier K, Petersen J, Schellander K, Wimmers K (2005) Divergent selection for $\omega 3: \omega 6$ polyunsaturated fatty acid ratio in quail eggs. Arch Tierz 48, 527-34 
Mielenz N, Dittmar E, Schüler L (2000) Effectiveness of genetic evaluation with transformed data by using dam-daughter pairs of Japanese quails. Arch Tierz 43, 299-309 [in German]

Narushin VG, Romanov MN (2002) Egg physical characteristics and hatchability. World's Poult Sci J 58, 297-303

Nasrollah V, Edriss MA, Moshtaghi H (2006) Comparison of egg weight between two quail strains. Int J Poult Sci 5, 398-400

Nowaczewski S, Kontecka H, Rosiñski A, Koberling S, Koronowski P (2010) Egg quality of Japanese quail depends on layer age and storage time. Folia Biol (Kraków) 58, 201-7

Oliveira CAF, Ogido R, Ledoux DR, Rottinghaus GE, Corrêa B, Reis TA, Gonçalez E (2007) The quality of eggs from Japanese quail, Coturnix japonica, fed rations containing Aflatoxin B1 and Fumonisin B1. J Poult Sci 44, 29-33

Petek M, Baspinar H, Ogan M (2003) Effects of egg weight and length of storage on hatchability and subsequent growth performance of quail. South Afr J Anim Sci 33, 242-7

Petek M, Baspinar H, Ogan M, Balci F (2005) Effects of egg weight and length of storage period on hatchability and subsequent laying performance of quail. Turk J Vet Anim Sci 29, 537-42

Ri E, Sato K, Oikawa T, Kunieda T, Uchida H, (2005) Effects of dietary protein levels on production and characteristics of Japanese quail eggs. J Poult Sci 42, 130-9

Roque L, Soares MC (1994) Effects of eggshell quality and broiler breeder age on hatchability. Poult Sci 73, 1838-45

Samli HE, Agma A, Senkoylu N (2005) Effect of storage time and temperature on egg quality in old laying hens. J Appl Poult Res 14, 548-53

Seker I (2004) Prediction of albumen weight, yolk weight, and shell weight as egg weight in Japanese quail eggs. J Fac Vet Med 23, 87-92

Şekeroğlu A, Altuntaş E (2009) Effects of egg weight on egg quality characteristics. J Sci Food Agric 89, 379-83

Sezer M (2007) Heritability of exterior egg quality traits in Japanese quail. J App Biol Sci 1, 37-40

Shanaway MM (1994) Quail production systems. Food and Agriculture Organization of the United Nations Rome, 1-135

Sultana F, Islam MS, Howlider MAR (2007) Effect of dietary calcium sources and levels on egg production and egg shell quality of Japanese quail. Int J Poult Sci 6, 131-6

Tarasewicz Z, Ligocki M, Szczerbińska D, Majewska D, Dańczak A (2006) Different level of crude protein and energy - protein ratio in adult quail diets. Arch Tierz 49, SI 2, 325-31

Tilki M, Saatci M (2004) Effects of storage time on external and internal characteristics in partridge (Alectoris graeca) eggs. Revue Med Vet 155, 561-4

Tserveni-Gousi AS (1987) Relationship between parental age, egg weight and hatching weight of Japanese quail. Br Poult Sci 28, 749-52

Williams KC (1992) Some factors affecting albumen quality with particular reference to Haugh unit score. World's Poult Sci J 48, 5-16

Woodard AE, Abplanalp H, Wilson WO, Vohra P (1973) Japanese quail husbandry in the laboratory (Coturnix coturnix japonica). Department of Avian Sciences University of California, David CA, 1-22

Yilmaz AA, Bozkurt Z (2009) Effects of hen age, storage period and stretch film packaging on internal and external quality traits of table eggs. Lucrări ştiințifice Zootehnie şi Biotehnologii 42, 462-9

Received 14 September 2009, accepted 21 July 2010.

Corresponding author:

SEBASTIAN NOWACZEWSKI

email: sebnow@jay.au.poznan.pl

Department of Poultry Science, Poznan University of Life Sciences, Witosa 45, 61-693 Poznan, Poland 